\title{
THE GUATTERIA GROUP DISENTANGLED: SINKING GUATTERIOPSIS, GUATTERIELLA, AND HETERopetalum INTO GUATTERIA
}

Roy H. J. Erkens ${ }^{1 *} \&$ Paul J. M. Maas ${ }^{2}$

\begin{abstract}
(The Guatteria group disentangled: sinking Guatteriopsis, Guatteriella, and Heteropetalum into Guatteria) The Guatteria group (Annonaceae) consists of four genera: Guatteria, Guatteriopsis, Guatteriella, and Heteropetalum. Morphological data have for long suggested a close affinity between these genera. Recent phylogenetic analysis has shown that Guatteriopsis, Guatteriella as well as Heteropetalum are actually nested within Guatteria. Here the nomenclatural consequences following from these results are presented. Three new combinations and one new name are introduced for Guatteriopsis and one old name is reinstated, one new combination and one new name is proposed for Guatteriella, and one old combination is reinstated for Heteropetalum. With the transference of the species of these three genera into Guatteria the concept of the Guatteria group is put out of use.
\end{abstract}

Key words: synonymy, new combinations, new names, reinstatement of old names.

Resumo

(O grupo Guatteria desvendado: fundindo Guatteriopsis, Guatteriella e Heteropetalum em Guatteria) O grupo Guatteria (Annonaceae) consiste de quatro gêneros: Guatteria, Guatteriopsis, Guatteriella e Heteropetalum. A afinidade entre estes quatro gêneros manteve-se aceita por longo tempo, com base em dados morfológicos. Entretanto, uma recente análise filogenética demonstra que Guatteriopsis, Guatteriella e Heteropetalum encontram-se circunscritos em Guatteria. As conseqüências nomenclaturais dos resultados filogenéticos obtidos são apresentadas neste trabalho. São propostas três combinações novas e um nome novo em Guatteriopsis, enquanto um nome antigo é restabelecido. Uma nova combinação e um novo nome são propostos em Guatteriella e uma combinação antiga é restabelecida em Heteropetalum. Com a transferência das espécies destes três gêneros para Guatteria, o conceito de grupo Guatteria não é mais necessário.

Palavras-chave: sinônimos, novas combinações, novos nomes, reestabelecimento de nomes antigos.

\section{INTRODUCTION}

The genus Guatteria Ruiz \& Pav. contains near to 290 species and is the largest genus within the family of Annonaceae (Erkens 2007). Species of Guatteria are frequent constituents of Neotropical (lowland) forests (Morawetz \& Waha 1985, Erkens et al. 2007) and the genus is widely distributed throughout Mesoamerica, the Caribbean, and tropical South America. Based on morphological characters, Guatteria belongs to Fries' Guatteria group (1939, 1943, 1959), consisting of four genera: Guatteria, Guatteriopsis R.E. Fr., Guatteriella R.E. Fr., and Heteropetalum Benth. (Fig. 1). The close affinity between these genera has been supported by data of many authors after Fries (e.g. leaf anatomy (van Setten \& KoekNoorman 1986), flower anatomy (van Heusden 1992), fruit and seed morphology (van Setten $\&$ Koek-Noorman 1992), unusual chromosome differentiation and cuticular folding patterns (Morawetz \& Waha 1985), a distinct pollen type (Walker 1971; Morawetz \& Waha 1985), oil composition analysis (Maia et al. 2005), and wood anatomy (Erkens et al. 2007)). These studies suggested a close affinity of the four genera but did not determine their phylogenetic relationships with respect to each other. In a recent phylogenetic study of the Guatteria group (Erkens et al. 2007) it was shown that Guatteriopsis, Guatteriella as well as Heteropetalum are all nested within Guatteria

Artigo recebido em 12/2007. Aceito para publicação em 03/2008.

${ }^{1}$ Utrecht University, Institute of Environmental Biology, Section Plant Ecology and Biodiversity, Sorbonnelaan 16, 3584 CA, Utrecht, The Netherlands.

${ }^{2}$ Nationaal Herbarium Nederland - Utrecht branch, Heidelberglaan 2, 3584 CS, Utrecht, the Netherlands.

*Author for correspondence: R.H.J.Erkens@uu.nl, 0031-30-2536845 

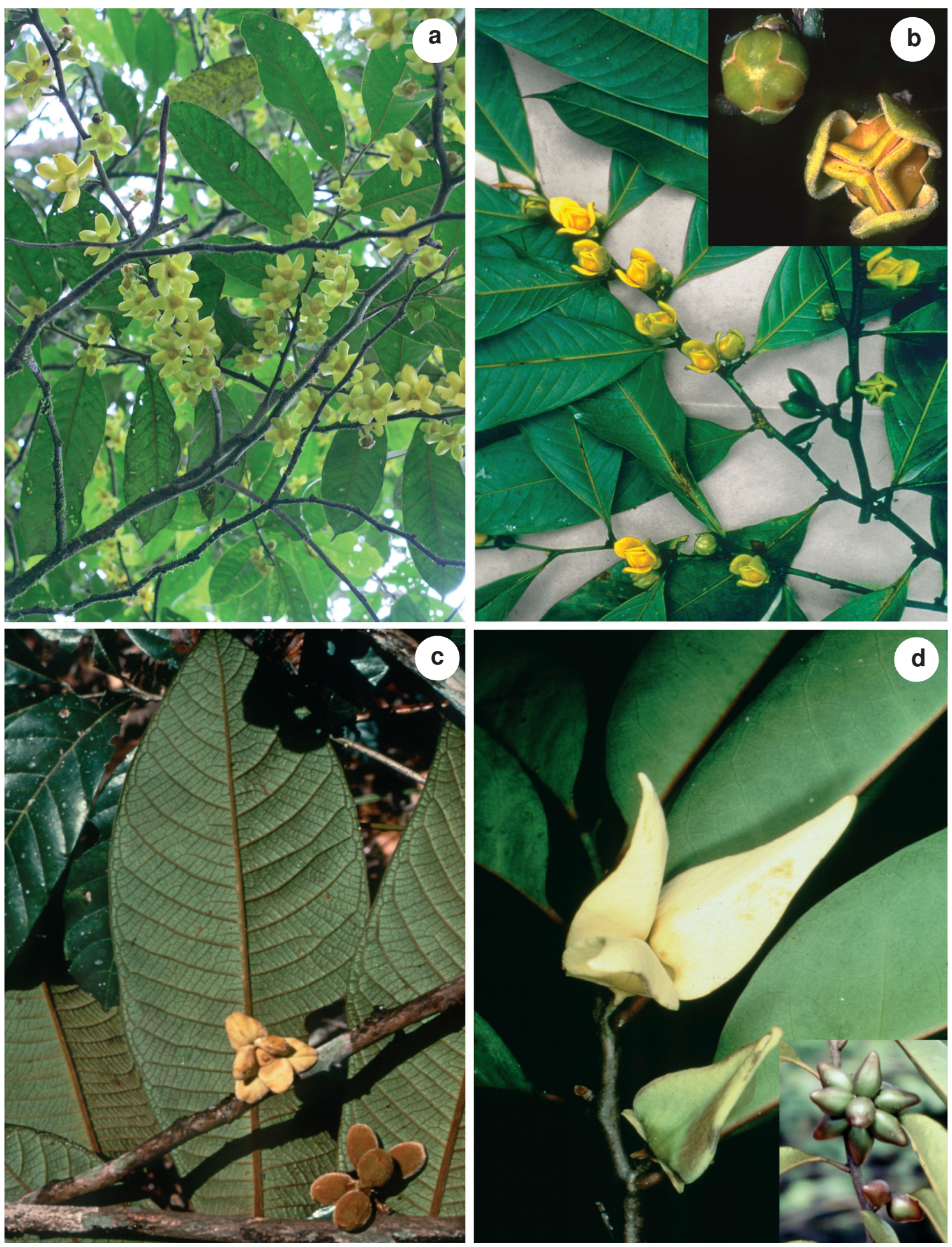

Figure 1 - Representatives of the former Guatteria group. a. flowering branch of Guatteria allenii. (Maas 9543); b. flowering branch of Guatteria blepharophylla (Harley 10962); inset shows close up of flower at anthesis and flower bud (Maas 8365); c. flowering and fruiting branch of Guatteria campinensis (Morawetz 31-24883); d. flowering branch of Guatteria heteropetala showing flower at anthesis and flower bud; inset shows fruiting branch. Photo credits: a. R.H.J. Erkens; b. P.J.M. Maas; c. W. Morawetz; d. G.A. Romero; inset: P.E. Berry. 
(Fig. 2). Therefore, a separate generic status of these three genera is unjustified. All species in these three genera should thus be transferred to Guatteria. Here the nomenclatural changes that follow from the aforementioned results are presented.

\section{NeW COMBinations}

Guatteria is easily recognised by a combination of an impressed primary vein on the upper side of the leaf, valvate sepals, almost always imbricate petals, numerous carpels (with a single basal ovule), and a pedicel with a distinct suprabasal articulation.

\section{Guatteriopsis R.E.Fr.}

Guatteriopsis ('Guatteria-like'; Fries 1934) has been distinguished from Guatteria by the fact that both whorls of petals are valvate (non-overlapping) instead of imbricate (overlapping). Guatteriopsis was made up of five species: the relatively widespread $G$. blepharophylla (Mart.) R.E. Fr. (Amazonian Brazil, Peru, Ecuador, Venezuela, and Guyana), G. friesiana W.A. Rodrigues (Amazonian Brazil and Colombia), G. hispida R.E. Fr. (Amazonian Brazil), G. kuhlmannii R.E. Fr. (Amazonian Brazil), and G. ramiflora D.R. Simpson (Amazonian Peru).

The molecular data presented by Erkens et al. (2007) show that Guatteriopsis is not a monophyletic clade within Guatteria. Guatteriopsis consists of three unrelated lineages. The first lineage comprises Guatteriopsis blepharophylla and G. hispida. These two species were described first (Fries 1934) and possess the synapomorphies that define the genus: flowers on short pedicels, valvate petals and an articulation nearer to the flower when compared to Guatteria. It can be seen from Figure 2 that these two species are sister to each other. Guatteriopsis blepharophylla was originally described as Guatteria blepharophylla and here this name is resurrected, following Johnson \& Murray (1995). Additionally, from the four syntypes of this species, namely von Martius s.n. (3

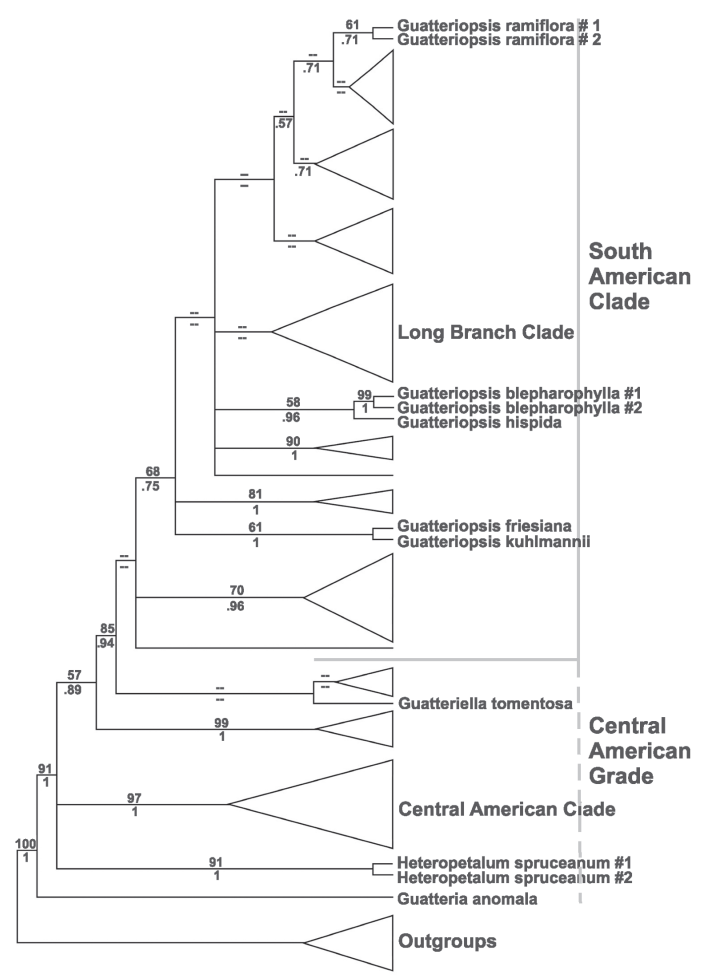

Figure 2 - Schematic representation of relationships between the members of the former Guatteria group (Erkens et al. 2007; triangles indicate recovered clades). Bootstrap support values are shown above the branches, Bayesian posterior probability values below. Names refer to those used by Erkens et al. (2007).

specimens) and Poeppig 3110, we have selected a von Martius collection as lectotype. Guatteriopsis hispida is simply transferred into Guatteria hispida.

Originally, there was a sixth species described into Guatteriopsis (G. sessiliflora (Benth.) R.E. Fr.) but this species has already been synonymized with Guatteriopsis blepharophylla (Erkens 2007, p. 264).

The second Guatteriopsis lineage (Fig. 2) consists of Guatteriopsis friesiana (Rodrigues 1981) and G. kuhlmannii (Fries 1937), two species that were described later into the genus. Both species have a rounded to cordate leaf base which separates them from G. blepharophylla and G. hispida. Furthermore, G. friesiana differs from the other species of Guatteriopsis in having ovoid 
instead of despressed ovoid flower buds. In a phylogenetic context, these species are also sister to each other, as shown in Figure 2. Guatteriopsis friesiana is transferred to Guatteria friesiana. Guatteriopsis kuhlmannii needs a new name in Guatteria because the epithet kuhlmanii is already occupied in Guatteria. The newly chosen epithet cryandra ('cold man') is a latinization of 'cool' (the English phonetic form of the German 'kuhl') and 'man' (after the german 'Mann').

Guatteriopsis ramiflora is the most recently described Guatteriopsis species (Simpson 1982). However, it is very clear on the basis of morphological characteristics and molecular data that this species has erroneously been described into Guatteriopsis: the petals are imbricate, the pedicel is $2.5-4 \mathrm{~cm}$ long (in Guatteriopsis $<1 \mathrm{~cm}$ ) and the articulation is suprabasal. Therefore, this species should not have been described as Guatteriopsis in the first place. As a consequence, the name of this species is here changed to Guatteria ramiflora.

Guatteria blepharophylla Mart. in Mart., Fl. bras. 13(1): 38. 1841.

Guatteriopsis blepharophylla (Mart.) R.E. Fr. Acta Horti Berg. 12: 110. t. 6. 1934. BRAZIL. PARÁ: Coari 'In silvis ad Coari, prov. Rio Negro, November 1819', C.F.P. von Martius s.n. (lectotype designated here: M). BRAZIL. PARÁ: Coari ('In sylvis ad Coari, provinciae Rio Negro, January 1820'), C.F.P. von Martius s.n. (syntype: M). BRAZIL ('Guatteria blepharophylla Mart.'), C.F.P. von Martius s.n. (syntype: M). BRAZIL. AMAZONAS, Tefé ('Ega'), E.F. Poeppig 3110 (syntypes: B, BM, GOET, P, W).

Annona sessiliflora Benth., Hooker's J. Bot. Kew Gard. Misc. 5: 8. 1853. Guatteria sessiliflora (Benth.) Saff., Contr. U. S. Natl. Herb. 18: 6. 1914. Guatteriopsis sessiliflora (Benth.) R.E. Fr., Acta Horti Berg. 12: 109. 1934. BRAZIL. AMAZONAS: Rio Negro, towards confluence with Rio Solimões, V.1851, R. Spruce 1668 (holotype: K; isotypes: BM, LE, M, NY, W ).
Guatteria friesiana (W.A. Rodrigues) Erkens \& Maas, comb. nov.

Guatteriopsis friesiana W.A. Rodrigues, Acta Amazonica 11: 49. f. 1. 1981. BRAZIL. AMAZONAS: Manaus, Igarapé Passarinho, 14.III.1956, D. Cô̂lho s.n. (holotype: INPA 3609; isotype: $\mathrm{S})$.

Guatteria hispida (R.E. Fr.) Erkens \& Maas, comb. nov.

Guatteriopsis hispida R.E. Fr., Acta Horti Berg. 12: 111. t. 7 \& 8. 1934. BRAZIL. AMAZONAS: Manaus, Estrada do Aleixo, $\mathrm{km}$ 12, 9.XII.1932, A. Ducke s.n. (holotype: S; isotypes: K, RB 23903, US).

Guatteria cryandra Erkens \& Maas, nom. nov. Guatteriopsis kuhlmannii R.E. Fr., Acta Horti Berg. 12: 275. t. 8. 1937. BRAZIL. PARÁ: Rio Tucuruí, affluent of Rio Xingu, Victoria, 17.IV.1924, J.G. Kuhlmann s.n. (holotype: S; isotype: RB 24361). Not Guatteria kuhlmannii R.E. Fr. (1939).

Guatteria ramiflora (D.R. Simpson) Erkens \& Maas, comb. nov.

Guatteriopsis ramiflora D.R. Simpson, Phytologia 51: 305. 1982. PERU. San Martín: Prov. Mariscal Caceres, Tocache Nuevo, Quebrada de Ishichimi (Fundo Retiro), 15.IV.1970, J. Schunke V. 3924 (holotype: F; isotypes: COL, F, MO, P, S, U, US).

\section{Guatteriella R.E. Fr.}

Guatteriella ('small Guatteria'; Fries 1939) is a rare and little known genus and consists of only two species: $G$. campinensis Morawetz \& Maas (Amazonian Brazil; Morawetz \& Maas 1984) and G. tomentosa R.E. Fr. (Amazonian Brazil and Colombia; Fries 1939). The genus has been characterized by laterally flattened (hairy) monocarps, thick and densely hairy, brownish yellow petals, and a percurrent, straight, tertiary venation. Only one species was used for the phylogenetic analysis of Figure 2. However, because of the synapomorphies that unite these two species it is expected that they are sister species and 
both should be placed in Guatteria. Guatteriella campinensis is renamed to Guatteria campinensis. Because the name Guatteria tomentosa is already in use, Guatteriella tomentosa is renamed Guatteria trichocarpa. The latter name is chosen because of the very hairy monocarps of this species.

Guatteria campinensis (Morawetz \& Maas) Erkens \& Maas, comb. nov.

Guatteriella campinensis Morawetz \& Maas, Pl. Syst. Evol. 148: 20.f. 12. 1984. BRAZIL. AMAZONAS: km 165 of road from Manaus to Itacoatiara, 24.VIII.1983, W. Morawetz \& D. Coêlho 3124883 (holotype: INPA; isotypes: $\mathrm{U}, \mathrm{WU})$.

Guatteria trichocarpa Erkens \& Maas, nom. nov.

Guatteriella tomentosa R.E. Fr., Acta Horti Berg. 12: 541. f. 39. 1939. BRAZIL. AMAZONAS: Rio Solimões, São Paulo de Olivença, 25.II.1932, A. Ducke s.n. (holotype: $\mathrm{S}$; isotype: RB 23916). Not Guatteria tomentosa Rusby (1910).

\section{Heteropetalum Benth.}

The fourth genus in the former Guatteria group was Heteropetalum ('unequal petals'; Fries 1930) made up of two species $(H$. brasiliense and $H$. spruceanum, both from Amazonian Brazil, southern Venezuela, and southern Colombia). Heteropetalum differed from Guatteria because its outer petals are greatly reduced in size (becoming almost sepallike). Fries (1930) split $H$. spruceanum from $H$. brasiliense and split $H$. spruceanum var. longipetalum from $H$. spruceanum (in Maguire et al. 1957). However, the differences between these taxa are so small and subtle (e.g. smaller versus larger leaves; more versus fewer secondary veins) that it is preferred here to unite them again, as was for instance preliminary done by Steyermark \& Berry (1995). Furthermore, the basionym of $H$. brasiliense, which is Guatteria heteropetala, is taken up again.
Guatteria heteropetala Benth., London J. Bot. 2: 360. 1843

Heteropetalum brasiliense Benth. J. Proc. Linn. Soc., Bot. 5: 69. 1860. BRAZIL. AMAZONAS: Rio Negro, 1839, R.H. Schomburgk I 950 (holotype K; isotypes BM, F, L, P, U).

Heteropetalum spruceanum R.E. Fr., Acta Horti Berg. 10: 75. t. 3. 1930. VENEZUELA. BOLÍVAR: Río Pasiba ('Vasiva'), affluent of Río Casiquiare, XII.1853, R. Spruce 3184 (holotype: $\mathrm{B}$; isotypes: BM, BP, C, E, K, MG, NY, P).

Heteropetalum spruceanum var. longipetalum R.E. Fr., Mem. New York Bot. Gard. 9: 330. 1957. COLOMBIA. Guainia: Río Atabapo, between San Fernando de Atabapo and Cacagual, 18.XI.1953, B. Maguire et al. 36261 (holotype: NY; isotype: S).

\section{ACKNOWLEDGEMENTS}

The authors thank Lubbert Westra for his help with the new Latin epithets, Sylvia Mota de Oliveira for her translation of the English title, abstract and keywords into Portuguese, and Christian Bräuchler and Hans-Joachim Esser for providing digital images of the type specimens of Guatteria blepharophylla from the Munich Herbarium (M). We also thank two anonymous reviewers for suggesting useful improvements of the manuscript.

\section{REFERENCES}

Erkens, R. H. J. 2007. From morphological nightmare to molecular conundrum. Phylogenetic, evolutionary and taxonomic studies on Guatteria (Annonaceae). PhD-thesis. Utrecht University, Utrecht, the Netherlands (electronically available at: http://igitur-archive.library.uu.nl/ dissertations/2007-0227-200317/ UUindex.html).

Erkens, R. H. J.; Chatrou, L. W.; KoekNoorman, J.; Maas, J. W. \& Maas, P. J. M. 2007. Classification of a large and widespread genus of Neotropical trees, 
Guatteria (Annonaceae) and its three satellite genera Guatteriella, Guatteriopsis and Heteropetalum. Taxon 56: 757-774.

Fries, R. E. 1930. Revision der Arten einiger Annonaceen-Gattungen I. Acta Horti Bergiani 10: 1-128.

1934. Revision der Arten einiger Annonaceen-Gattungen III. Acta Horti Bergiani 12: 1-220.

1937. Revision der Arten einiger Annonaceen-Gattungen IV. Acta Horti Bergiani 12: 221-288.

1939. Revision der Arten einiger Annonaceen-Gattungen V. Acta Horti Bergiani 12: 289-577.

1943. Einige Gesichtspunkte zur systematischen Gruppierung der amerikanischen Annonaceen-Gattungen. Arkiv för Botanik 30A: 1-31.

1959. Annonaceae. In: Melchior, $\mathrm{H}$. (ed.). Die natürlichen Pflanzenfamilien... begründet von A. Engler und K. Prantl, vol. 2, 17a II: 1-171. Duncker \& Humblot, Berlin.

van Heusden, E. C. H. 1992. Flowers of Annonaceae: morphology, classification, and evolution. Blumea (Suppl.) 7: 1-218.

Johnson, D. M. \& Murray, N. A. 1995. Guatteria Ruiz \& Pav. In: Steyermark, J. A.; Berry, P. E. \& Holst, B. K. (eds.). Flora of the Venezuelan Guyana, vol. 2. Timber Press, Portland. Pp. 441-451.

Maguire, B.; Wurdack, J. J. \& Collaborators 1957. The botany of the Guayana highland - part II. Memoirs of The New York Botanical Garden 9: 235-392.

Maia, J. G. S.; Andrade, E. H. A.; Carreira, L. M. M.; Oliveira, J. \& Araújo, J. S. 2005.
Essential oils of the Amazon Guatteria and Guatteriopsis species. Flavour and Fragrance Journal 20: 478-480.

Morawetz, W. \& Maas, P. J. M. 1984. Notes on the systematics of the Amazonian genus Guatteriella (Annonaceae). Plant Systematics and Evolution 148: 19-23.

Morawetz, W. \& Waha, M. 1985. A new pollentype, C-banded and fluorochrome counterstained chromosomes, and evolution in Guatteria and related genera (Annonaceae). Plant Systematics and Evolution 150: 119-141.

Rodrigues, W. A. 1981. Guatteriopsis friesiana W. Rodrigues, nova espécie de Annonaceae para a Amazônia. Acta Amazonica 11: 49-51.

van Setten, A. K. \& Koek-Noorman, J. 1986. Studies in Annonaceae. VI. A leafanatomical survey of genera of Annonaceae in the Neotropics. Botanische Jahrbücher für Systematik, Pflanzengeschichte und Pflanzengeographie 108: 17-50.

1992. Studies in Annonaceae. XVII.

Fruits and seeds of Annonaceae: morphology and its significance for classification. Bibliotheca Botanica 142: 1-101.

Simpson, D. R. 1982. New species from South America III. Phytologia 51: 305-308.

Steyermark, J. A. \& Berry, P. E. 1995. Heteropetalum Benth. In: Steyermark, J. A.; Berry, P. E. \& Holst, B. K. (eds.). Flora of the Venezuelan Guayana, vol. 2. Timber Press, Portland. Pp. 452-453.

Walker, J. M. 1971. Pollen morphology, phytogeography and phylogeny of the Annonaceae. Contr. Gray Herb. 202: 1-133. 